\title{
A UNIVERSIDADE E O PROJETO CIÊNCIA NA ESCOLA E NA FAMÍLIA: RELATO DE UMA EXPERIÊNCIA
}

\author{
*Sergio Oliveira Moraes, **Maria Lídia Romero Meira
}

\section{RESUMO}

O presente trabalho descreve um projeto desenvolvido junto à E.E. "Pedro de Mello", da rede estadual de ensino, localizada no distrito de Tupi, município de Piracicaba, São Paulo, em parceria com o Centro Ecológico Flora Guimarães Guidotti e financiado pelo Fomento às Iniciativas de Cultura e Extensão (antigo Fundo de Cultura e Extensão Universitária) da Pró-Reitoria de Cultura e Extensão Universitária da USP, com os seguintes objetivos: a) fortalecer o vínculo entre a Escola Superior de Agricultura "Luiz de Queiroz" (ESALQ) e a comunidade piracicabana; b) contribuir para a inclusão científica e compreensão multidisciplinar do ensino de Giências; c) contribuir para o debate da questão ambiental na escola; d) difundir tecnologias sustentáveis, criativas e de baixo custo para a comunidade escolar e seu entorno. Os resultados indicam que os objetivos foram razoavelmente atingidos. Foram realizadas oficinas e shows de Física que permitiram a discussão, construção e instalação das tecnologias na escola e visitas ao centro ecológico que permitiram a interação com as tecnologias em funcionamento. Todas as atividades tiveram material didático de apoio aos professores especialmente produzido.

Palavras-chave: Educação. Ciência. Ambiente.

\section{ABSTRACT}

This paper describes a project involving "E.E. Pedro de Mello", an under graduate public school located at Tupi district, in the city of Piracicaba, São Paulo, in a partnership with the Centro Ecológico Flora Guimarães Guidotti (Ecological Center Flora Guimarães Guidotti), and supported by the Culture and Extension Fund from the Associate Dean's Office of Culture and Extension of the University of São Paulo, with the following objectives: a) to strengthen the bond between Escola de Agricultura "Luiz de Queiroz" (Luiz de Queiroz College of Agriculture) and Piracicaba's community; b) to contribute to scientific inclusion and multidisciplinary understanding of science education; c) to contribute with environmental debate at school; d) to diffuse sustainable, creative and low coast technologies at school and it's neighborhood. The results and discussions allowed to conclude that the objectives where reasonably reached, with workshops and Physics shows that provided the discussion, construction and implementation of the technologies in the school; the visits to the Ecological Center also provided the interaction with the operating technologies. All the activities used didactical material especially produced for the teachers.

Key words: Education. Science. Environment.

\footnotetext{
* Professor do Departamento de Ciências Exatas da Escola Superior de Agricultura "Luiz de Queiroz" da Universidade de São Paulo (ESALQ-USP). ** Coordenadora do Centro Ecológico Flora Guimarães Guidotti - Fundação de Estudos Agrários "Luiz de Queiroz" (FEALQ). Endereço: Av. Pádua Dias, II - I34I8-900 - Piracicaba-SP - e-mail: somoraes@esalq.usp.br
} 


\section{INTRODUÇÃO}

Que o Brasil passa por enormes dificuldades no quesito cultura e no ensino, em particular, não é novidade. Nós, professores, as sentimos na própria pele ou melhor dizendo, na própria sala de aula e a população recebe a informação continuamente via meios de comunicação. Talvez nesse ponto um círculo vicioso se torne mais evidente e perverso, pois, ao mesmo tempo em que há acesso à informação sobre os problemas do ensino, qual o percentual da população que consegue compreender a informação, devido a sua própria deficiência de aprendizagem? Um vislumbre da dimensão do problema pode ser obtido da leitura do texto de Suely Druck:

A progressiva decadência da qualidade deste ensino da Matemática atinge hoje a própria licenciatura em Matemática, completando assim um círculo vicioso. Dados objetivos evidenciam o problema: no Provão, a Matemática tem sido a última colocada em todos os anos e dentre todas as áreas avaliadas... (DRUCK, 2003)

Mais adiante, no texto:

...Um parecer do Instituto Paulo Montenegro (Ibope), de I7.I2.02, sobre o índice de conhecimento matemático da população no país, entre I5 e 64 anos, mostra a que ponto chegou a calamidade nacional na questão do ensino da Matemática: a indicação de que apenas 2I\% da população consegue compreender informações a partir de gráficos e tabelas, frequentemente estampadas nos veículos de comunicação, sugere que boa parte dos brasileiros encontra-se privada de participação efetiva na vida social, por não acessar dados e relações que podem ser importantes para auxiliá-la na avaliação de situações e na tomada de decisões. (DRUCK, 2003)

Vale lembrar que, à época, a professora Suely Druck era presidente da Sociedade Brasileira de Matemática. A escolha dessa disciplina para exemplificar a crise na Educação poderia, eventualmente, ser criticada como um caso extremo - a disciplina, por si só, apresentaria dificuldades -, mas não é o caso. Uma semana antes, Gilberto Dimenstein publicou um artigo com o seguinte título: 180 mil jovens não conseguiram ocupar 872 empregos (DIMENSTEIN, 2003). São, grosso modo, 206 vagas para cada candidato e, estas, não foram preenchidas. Nessa avaliação, o que foi levado em conta, além de uma boa base escolar, inglês fluente, conhecimento de informática, experiências em empresas juniores e atividades extracurriculares, foram atitudes como: iniciativa, persistência, comunicação, trabalho em equipe, flexibilidade e raciocínio analítico. Ou seja, é requisitado ao aluno não só conteúdo, mas atitudes, as quais a escola também pode contribuir para que se desenvolvam. Some-se ao anterior um outro texto, divulgado alguns dias antes, também publicado na Folha de S. Paulo, intitulado "Como a escola mata a vontade de aprender", no qual a autora diz:

A escola deve ensinar o aluno a pensar, a pesquisar, a se dedicar e a procurar as respostas para as questões que o conhecimento suscita. Hoje, a escola está mais preocupada em dar as respostas para fazer o aluno aprender (SAYÃO, 2003).

Propositadamente, os textos até agora indicados são do mesmo mês e ano e colocam a seguinte questão: como trabalhar com a escola e seus estudantes de maneira a não ignorar as dificuldades de formação dos professores (DRUCK, 2003), trabalhar o conteúdo de forma multidisciplinar, mas ir além dele provocando atitudes (DIMENSTEIN, 2003), sem matar a vontade de aprender, mas estimulando-a (SAYÃO, 2003). Na tentativa de contribuir para a melhoria desse cenário, foi apresentado o Projeto Giência na Escola e na Família à E. E. "Pedro de Mello", da rede estadual de ensino, em parceria com o Centro Ecológico Flora Guimarães Guidotti e financiado pelo Fomento às Iniciativas de Cultura e Extensão da Pró-Reitoria de Cultura e Extensão Universitária da USP, com os seguintes objetivos: a) fortalecer o vínculo entre a ESALQ e a comunidade Piracicabana; b) contribuir para a inclusão científica e compreensão multidisciplinar do ensino de Giências; c) contribuir para o debate da questão ambiental na escola; d) difundir tecnologias sustentáveis, criativas e de baixo custo para a comunidade escolar e seu entorno. 


\section{MATERIAL E MÉTODOS}

\section{PARCEIROS NOS INVESTIMENTOS}

O projeto, que durou de agosto de 2007 a junho de 2008, foi financiado pelo Fomento às Iniciativas de Cultura e Extensão da Pró-Reitoria de Cultura e Extensão Universitária da Universidade de São Paulo, o qual proporcionou recursos para bolsas de dois estudantes e para material de consumo empregado nas oficinas e visitas, entre outros. A Monte Alegre Agência de Turismo disponibilizou ônibus para o transporte dos estudantes ao Centro Ecológico e de volta à E.E. "Pedro de Mello".

\section{PARCEIROS TÉCNICO-CIENTÍFICOS}

\section{I.Programa Escola da Família e E.E. "Pedro de Mello": as} atividades do projeto foram planejadas em conjunto com a Escola da Família da E.E. "Pedro de Mello", um programa estadual que objetiva a abertura, nos finais de semana, de escolas da rede estadual de ensino, transformando-as em centros de convivência, para criar uma cultura da paz, despertar potencialidades e desenvolver hábitos saudáveis junto à juventude ${ }^{\mathrm{I}}$.

As atividades do programa organizam-se em torno de quatro pilares: cultura, esporte, saúde e qualificação para o trabalho. No ano de 2006, na E.E. "Pedro de Mello" foram realizadas atividades que abrangeram oficinas de alimentos saudáveis, bijuteria, padaria artesanal, jogos de quadra e de tabuleiro, exibição de filmes, dias de mutirão de limpeza, orientação médica, encontros de jovens, entre outros; e no ano de 2007, início do projeto, o foco foi aproximar mais os pais dos estudantes.

\section{Centro Ecológico Flora Guimarães Guidotti:} O Centro Ecológico é uma propriedade rural localizada na divisa dos municípios de Piracicaba e Rio das Pedras, dedicada à conservação ambiental, educação ambiental e difusão de tecnologias e técnicas que promovam uso e conservação dos recursos naturais. Recebe visitações, realiza projetos junto à comunidade, hospeda tecnologias, entre outras atividades. Seus projetos são orientados por docentes da ESALQ.

As tecnologias e atividades instaladas no Centro Ecológico durante a execução do projeto eram: horta orgânica, composteira, viveiro agroflorestal, secador solar industrial, secador solar de madeira, secador solar de caixa de frutas, aquecedor solar de água, área de agrofloresta, coletor de água de chuva, banheiro seco e trilha na mata. No Centro Ecológico, os visitantes encontraram as tecnologias em funcionamento - o aquecedor solar aquecendo a água, a horta produzindo hortaliças - e interagiram com as mesmas.

\section{METODOLOGIA CONCEITUAL E ATIVIDADES}

\section{TECNOLOGIAS E CONTEÚDOS CURRICULARES}

As tecnologias propostas, sempre focadas nos objetivos, foram pesquisadas e desenvolvidas em conjunto com a Universidade. Todas visam promover um melhor uso dos recursos naturais renováveis a um custo financeiro acessível e envolver o maior número possível de disciplinas do currículo escolar, como: Física, Ecologia, Biologia, Geografia, Matemática, História, etc., de forma a constituírem-se em laboratórios ao ar livre. Toda a comunidade escolar encontrará nelas exemplos diretamente relacionados ao conteúdo aprendido em sala de aula, podendo-se citar o Secador Solar de Frutas que permite trabalhar conceitos de:

- Geografia: movimentos de rotação e translação da Terra, pontos cardeais, latitude, clima, etc.;

- História: invasões dos povos em busca de alimento, regiões industrializadas e agrícolas, etc.;

- Matemática: ângulos, medidas de comprimento, área, volume, massa, estatística básica, etc.;

- Física/ Giências: energia, calor, temperatura, formas de transferência de calor, efeito estufa, energia elétrica, etc.;

- Biologia/ Giências: fotossíntese, respiração, água, ar, conservação de alimentos e micro-organismos, etc.

I 〈www.escoladafamilia.sp.gov.br> 


\section{VISITAS AO CENTRO ECOLÓGICO FLORA} GUIMARÃES GUIDOTTI

As visitas tiveram como eixo temático as tecnologias abordadas nas oficinas que aconteceram na escola, porém, trabalharam mais profundamente o contexto de cada uma. Os roteiros de atividades durante as visitas foram planejados para abordar o tema de forma lúdica e instigadora, utilizando jogos, atividades práticas e discussões. As turmas, com cerca de 30 estudantes, foram divididas em dois ou três grupos, cada um monitorado por um membro da equipe, permitindo um contato mais próximo e atencioso.

\section{OFICINAS NA ESCOLA}

Como atividades práticas principais foram realizadas na E.E. "Pedro de Mello" oficinas de construção e/ ou instalação das seguintes tecnologias: aquecedor solar de água, secador solar de frutas, sistema de captação de água da chuva, forno solar e composteira. Ocorreram sempre aos finais de semana, durante o Programa Escola da Família. Os participantes atuaram na construção e instalação das tecnologias na escola, o que possibilita que se tornem multiplicadores e editores das tecnologias na comunidade. Além das oficinas ocorreram também dois shows de Física.

\section{COLABORAÇÃO COM OS PROFESSORES \\ PARA UTILIZAÇÃO DAS TECNOLOGIAS NO \\ ENSINO DE CIÊNCIAS}

Os estudantes bolsistas do projeto colaboraram com os professores em suas atividades didáticas, produzindo apostilas sobre a utilização das tecnologias no ensino, envolvendo o maior número possível de disciplinas, roteiros para visitas e disponibilizando instruções de construção e instalação das tecnologias abordadas. Estes roteiros e apostilas poderão ser utilizados, inclusive, por professores que não tiveram participação no projeto, auxiliando-os a trabalhar com as tecnologias e propagando-as em outras instituições de ensino. Nesses textos auxiliares buscou-se sistematizar as seguintes informações:

- Sugestões de atividades didáticas com as tecnologias, para uso na escola;

- Roteiros de atividades lúdicas realizadas nas visitas ao Centro Ecológico Flora Guimarães Guidotti;

- Instruções de instalação das tecnologias;

- Textos de apoio relacionados às tecnologias.

\section{RESULTADOS}

A tabela I apresenta os temas das atividades desenvolvidas na E.E. "Pedro de Mello" e no Centro Ecológico e respectivos números de participantes.

TABELA 1

Atividades do Projeto Ciência na Escola e na Família e respectivos números de participantes.

\begin{tabular}{|l|l|}
\hline TEMA DA ATIVIDADE & $\begin{array}{l}\text { N. DE PARTI- } \\
\text { CIPANTES }\end{array}$ \\
\hline I Show de Física & $300^{*}$ \\
\hline Oficina Composteira & I2 \\
\hline Visita Tema Compostagem & 26 \\
\hline II Show de Física & $300^{*}$ \\
\hline Oficina Secador Solar & 32 \\
\hline Visita Tema Energia Solar & $3 \mathrm{I}$ \\
\hline Intervenção Captação de Água de Chuva & $90^{*}$ \\
\hline Oficina Forno Solar & I \\
\hline Oficina Aquecedor Solar de Água & I7 \\
\hline Visita Tema Água & 26 \\
\hline Visita Tema Horta Orgânica & 30 \\
\hline Visita Tema Horta Orgânica & 29 \\
\hline NúMERo TOTAL DE PARTICıPANTEs & $\mathbf{9 1 1}$ \\
\hline
\end{tabular}

* Dia letivo de reposição de aulas. Números aproximados conforme lista de presença do Programa Escola da Família.

As atividades no Centro Ecológico envolveram estudantes da quarta a oitava séries da E.E. "Pedro de Mello" e as oficinas e shows de Física envolveram os estudantes, familiares e comunidade do entorno escolar.

Para exemplificar as interconexões entre uma dada sequência de atividades, objetivando dar ao estudante uma visão não fragmentada da ciência, apresenta-se o "pacote" elaborado para o tema: Compostagem, compreendendo Oficina - Laboratório Multidisciplinar de Tecnologias Ambientalmente Adequadas para atividades na Escola, e Visita - Roteiro para Auxílio ao Professor, para atividades fora do ambiente escolar.

\section{OFICINA DE COMPOSTAGEM}

Foi realizada no dia $\mathrm{I}^{\mathrm{O}}$ de março de 2008 , como atividade inicial, para que o composto fosse produzido a partir dos resíduos gerados na Escola. Teve como 
objetivos a capacitação para a construção de uma composteira para a escola e a compreensão de seu funcionamento, manejo e utilidades.

A arrecadação do lixo orgânico mobilizou a escola e a comunidade, antes e após a oficina. Foram expostos resíduos no pátio que estimularam os participantes a manusear o material, discutir o que é lixo (figura I) e seus problemas, como a poluição causada pelos lixões, os custos envolvidos na destinação correta dos resíduos domésticos e as dificuldades de fiscalização adequada; as características de cada material, tempo de decomposição, o princípio dos 3 R's (I. redução no consumo e no desperdício; 2. reutilização de produtos; 3. reciclagem de materiais) e a reciclagem. Por fim, questionou-se como a compostagem pode ser uma solução prática, simples e de retorno positivo para quem a utiliza, uma vez que se produz adubo de bom uso para hortas.

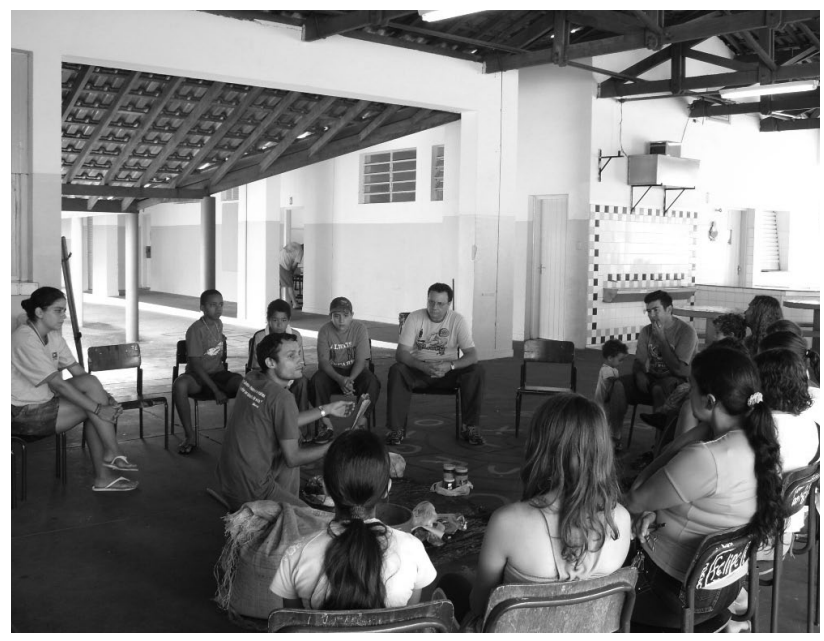

Figura I - Discussão sobre resíduos na Oficina de Compostagem

A pilha de composto foi montada próxima à cozinha e à horta da escola, devido à disponibilidade de água e facilidade de manejo. Cada etapa do processo foi detalhada durante a montagem da pilha de composto (figura 2) e discutida de forma a despertar a curiosidade sobre os fundamentos científicos envolvidos, evitando-se fornecer respostas conceituais diretas.

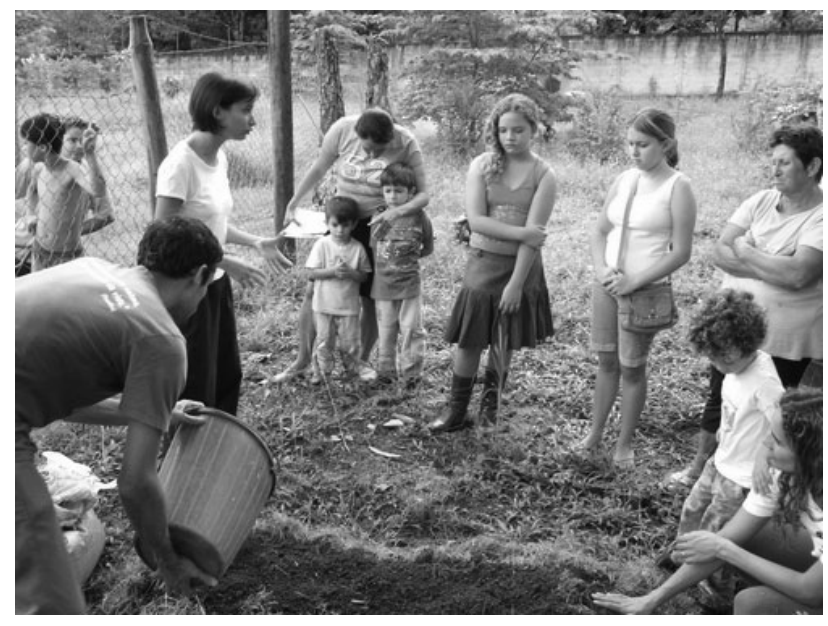

Figura 2 - Montagem da composteira durante a Oficina de Compostagem

Observou-se que algumas pessoas já conheciam a técnica e um dos participantes já tinha uma composteira instalada em sua casa. Ficou acertado que seria sugerido às merendeiras ou aos professores que quisessem desenvolver atividades com os estudantes, fazer a deposição na composteira dos resíduos orgânicos da escola ou trazidos de casa.

\section{MATERIAL COMPLEMENTAR}

O Apêndice A apresenta alguns tópicos do respectivo Material Complementar elaborado pelos bolsistas do projeto e voltado a auxiliar o professor na utilização da temática Compostagem como ferramenta de ensino.

\section{VISITA - TEMA COMPOSTAGEM}

A visita ocorreu em março de 2008 , com 26 estudantes da quinta série acompanhados pelo professor coordenador do Programa Escola da Família e seguiu um roteiro disponibilizado aos professores (apêndice B). A figura 3 mostra momentos dessa visita. 


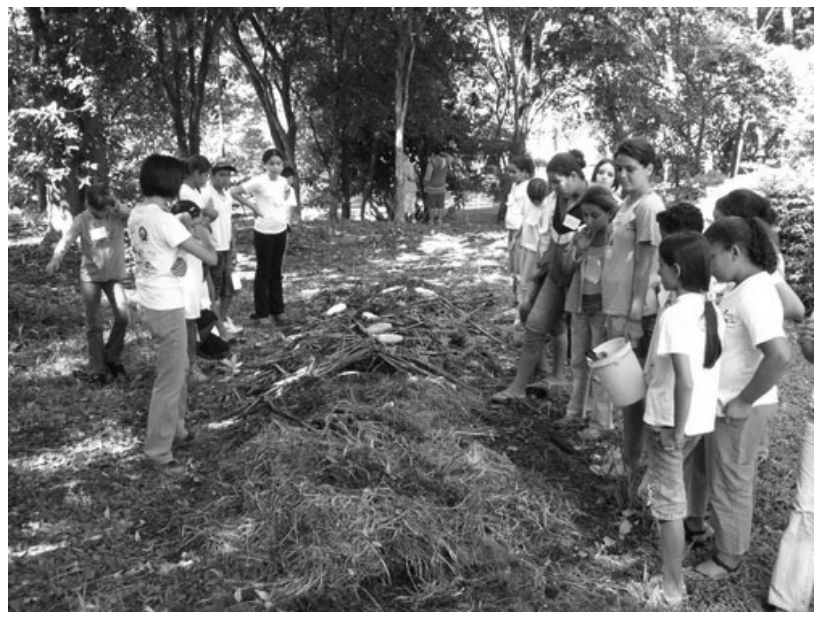

Figura 3 - Visita ao Centro Ecológico - Tema Compostagem.

\section{ROTEIRO ELABORADO PARA AUXÍLIO AO PROFESSOR} - TEMA COMPOSTAGEM E REsíduOS

Os roteiros das visitas foram sistematizados. $\mathrm{O}$ exemplo do roteiro da visita sobre compostagem pode ser visto no apêndice $B$.

\section{DISCUSSÃO}

A discussão tem como pano de fundo os objetivos do projeto, e dar-se-á primeiramente com reflexões acerca da participação dos professores e estudantes, seguidas de comentários sobre a execução das atividades em geral, na sequência: shows de Física, oficinas e visitas. Essa discussão por atividades pretende ser apenas didática, pois as atividades estão absolutamente ligadas.

O planejamento do Projeto aconteceu em conjunto com o Programa Escola da Família, a direção e coordenação da E. E. "Pedro de Mello", no primeiro semestre de 2007 talvez tenha sido a etapa mais crítica de todo o processo, não apenas por sua dificuldade intrínseca, mas por ter envolvido instituições com rotinas muito distintas, se é que a palavra rotina não é por demais simplificadora. Durante a realização das atividades, situações em parte não planejáveis e em parte oriundas da inexperiência da equipe da ESALQ quanto ao trabalho junto a docentes dos Ensinos Fundamental e Médio, contribuíram para um baixo envolvimento dos professores da Escola, aspecto considerado importantíssimo. E neste ponto não há nenhuma crítica a esta particular instituição, pois sabe-se que a quantidade de aulas que o professor dos Ensinos Fundamental e Médio públicos ministra, dificilmente o habilita para uma atividade extra aos sábados. Desse modo, foi efetivamente o professor coordenador do Programa Escola da Família, contexto em que se realizaram as Oficinas, quem participou de todas as etapas do Projeto. Some-se a esta dificuldade, o rodízio dos docentes nas escolas, isto é, muitos permanecem por um ano em uma unidade de ensino, depois vão para outra e assim sucessivamente. Talvez a expectativa de descontinuidade do Projeto no ano seguinte tenha desencorajado a participação. Outro fato ocorrido em 2008 foi de natureza pedagógica: a implementação da Nova Proposta Curricular do estado de São Paulo, que levou os docentes, a direção e a coordenação da Escola a se prepararem e priorizarem as novas orientações, que transformaram o cenário para o qual o Projeto fora planejado. Estas considerações justificam o baixo envolvimento docente, principalmente nas oficinas.

Os shows de Física (figura 4) ocorreram no pátio da Escola, num modelo interativo e participativo (SAAD, I998), com envolvimento de um grande número de estudantes, seus familiares, moradores do entorno escolar e professores. A figura 5 cria a pretensão de que o emocional dos presentes foi tocado (SAAD, I998, 200I).

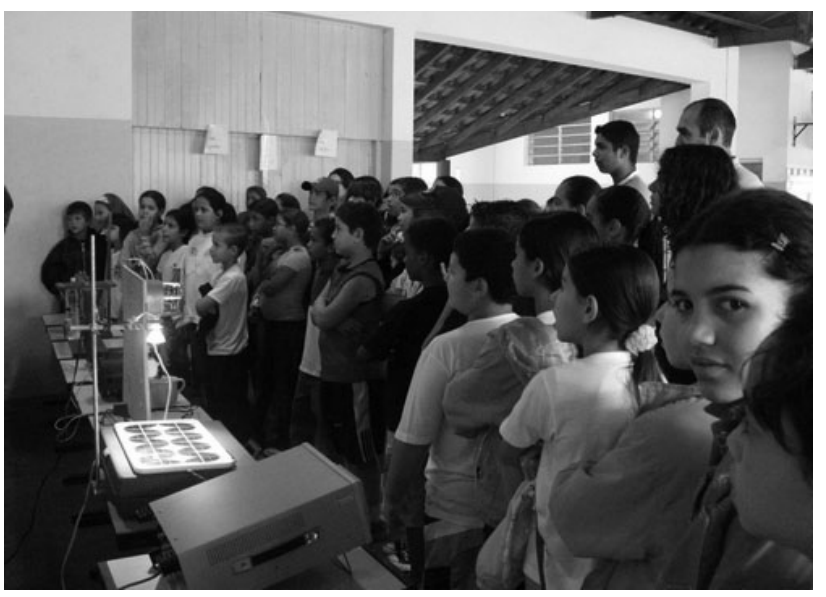

Figura 4-Show de Física 


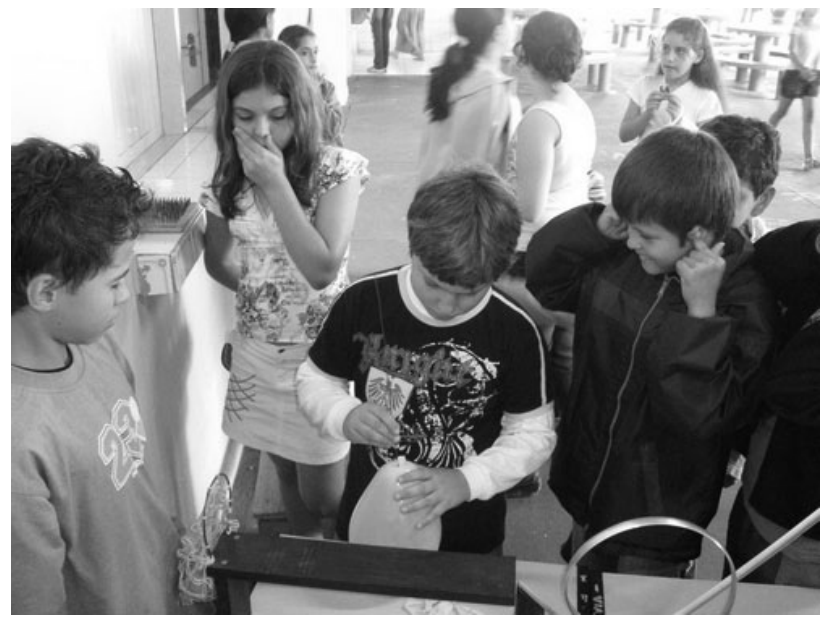

Figura 5 - Show de Física

O planejamento e execução dos shows seguiram duas orientações: I. a sequência de demonstrações devia estar circunscrita aos objetivos do projeto, isto é, não utilizar nada que embora interessante ou surpreendente, estivesse fora dos objetivos; 2. estar o mais próximo possível do dia a dia dos estudantes e familiares, possibilitando enxergar a ciência no cotidiano (ARGÜELLO, 200I).

Assim, a temática energia e sua utilização racional permeou as demonstrações, partindo dos conceitos de força, pressão, trabalho, energias potencial e gravitacional se transformando em cinética, que se transforma em elétrica, com perdas na forma térmica e sonora, até chegar aos trafos abaixadores de tensão. Depois dessa etapa mais conceitual passava-se a um painel demonstrativo do consumo de aparelhos elétricos domésticos (motor, lâmpada e ebulidor), com medidor de energia, tensão e corrente, painel com lâmpadas incandescentes e fluorescente compacta, culminando em um painel fotovoltaico ligado a um osciloscópio (os únicos instrumentos comparativamente sofisticados), para mostrar uma energia não convencional. Este conjunto permite formar um quadro da geração de energia elétrica por uma hidroelétrica e as consequências do gasto excessivo de água, no nível das represas e na geração da energia, entre outros.

A segunda orientação, aparelhos não "mágicos" e ligados ao dia a dia dos participantes permitiu conquistar pais e professores, que não foram intimidados por uma "parafernália" pouco amigável e possíveis perguntas embaraçosas de filhos e alunos, nas palavras de Argüello (200I, p. I46): "Ciência a meu ver é um processo, não é um pedaço de equipamento ou um display, por mais bonito que possa ser. A ciência tem de ser vivida. Ela não pode nem sequer ser observada."

As oficinas propositadamente precederam as respectivas Visitas e dessa forma os estudantes tinham a oportunidade de "por a mão na massa", antes de ver o objeto pronto no Centro Ecológico, não permitindo portanto uma comparação prévia. Também não se desejava uma coleção de aparelhos para uma feira de ciências, visíveis apenas nos dias da feira, mas aparelhos ou tecnologias que pudessem permanecer visíveis na escola e que pudessem ser feitos em casa, com pouca habilidade ou gasto extra, ou seja, a preocupação com o que Burke chama de significado:

O significado de alguma coisa para o indivíduo é sempre a assimilação dessa coisa às estruturas que formam seu universo mental. A rigor, portanto, há tantos significados para um mesmo objeto quanto são os indivíduos que tiverem tido contato com ele, e os significados serão, também, mais ou menos móveis para cada indivíduo. (BURKE, 2003, p. 3I)

A questão do significado talvez possa explicar a dificuldade de muitos para adotar procedimentos aparentemente simples como separar o lixo orgânico, reciclar ou reutilizar garrafas, latas, etc. Essa assimilação, pressuposta pelo significado é, por sua vez:

...um conceito biológico: o organismo retira do meio que o cerca determinados elementos, como o alimento, e os transforma de acordo com suas próprias estruturas, isto é, modifica as estruturas daquilo que capta no meio, de forma que estas se tornem compatíveis com as estruturas do organismo. (BURKE, 2003, p. 30)

A questão do significado colocou-se pelo seguinte: os aparelhos e tecnologias são laboratórios multidisciplinares para os professores e permitem ou devem permitir a aprendizagem fora da sala de aula, o que Dimenstein coloca enfaticamente: "Para mim, o mundo era fantástico, então, achava um absurdo todo mundo ficar parado. Eu queria sair, passear, mexer nas árvores..." (DIMENSTEIN \& ALVES, 2003).

Mas os dispositivos e tecnologias devem servir também para gerar mudanças de comportamento com relação ao ambiente, no seu sentido mais amplo. 
Exemplificando, há uma diferença básica entre estudar calor, temperatura, formas de transferência de energia térmica em um laboratório munido de vidrarias, termômetros e calorímetros e fazê-lo desidratando frutas e hortaliças ou aquecendo a água do chuveiro ou da pia com energia solar. É de se supor que o significado possa ser mais facilmente apreendido no segundo caso e a desejada mudança de comportamento facilitada. Como os estudantes podem reproduzir as tecnologias em suas casas, espera-se que, seja pela escola, seja pela presença em casa, a mudança de hábitos seja estimulada em mais pessoas.

As visitas contaram com um número maior e mais estável de participantes (tabela I), pois além de acontecerem em horário de aula, despertaram a curiosidade por ser fora da escola. O Centro Ecológico permite localmente aquilo que a pequena Carol, na época com doze anos, concluiu, após muitas visitas a centros de ciência no exterior: "as crianças, no Brasil, para realizarem suas pesquisas vão às bibliotecas, quando possível, enquanto nos outros países vão aos museus, onde tudo é interessante e mais fácil de aprender"; e seu pai, o ouvinte, explica: "Na realidade, ela quis demonstrar que os museus e centros de ciências funcionam como verdadeiras enciclopédias vivas, colaborando com o currículo escolar e facilitando o aprendizado." (CASTRO, I998, p.I08). Embora a cidade de Piracicaba contemple outros museus, inclusive na ESALQ, foi decidido apresentar um local em que as tecnologias abordadas com os professores e estudantes são utilizadas de forma rotineira, isto é, não são objetos de exposição, mas elementos constitutivos do próprio local.

Acredita-se que o fato dos estudantes da E.E. "Pedro de Mello" se relacionarem com o meio rural (por ser uma escola localizada em um distrito de Piracicaba que convive lado a lado com o ambiente urbano e o rural), contribuiu para o desenvolvimento do referido significado. O fato de muitos pais de estudantes terem uma horta, árvores frutíferas e criações de animais domésticos em suas chácaras ou sítios, torna-os potenciais usuários das tecnologias trabalhadas: há que cuidar da horta; dar um destino para os restos de matéria orgânica produzida em grande quantidade (seja por opção pela agricultura orgânica, seja para baixar o custo de produção); desidratar frutas e hortaliças para evitar perdas; guardar a água de chuva para a época de estiagem, são situações vividas por famílias dessa comunidade escolar, compartilhadas pelos filhos e que precisam de uma solução. A escola poder contribuir é o sentido correto do ensino (BURKE, 2003), a solução a partir de problemas. Então, mostrar essas tecnologias em funcionamento é uma tentativa de fazer com que sejam adotadas na propriedade familiar. Se eu aprendi a fazer e funciona... Como seria trabalhar os mesmos conteúdos com estudantes exclusivamente urbanos?

De particular importância foi o roteiro (apêndice B) associado a cada visita, em que a intenção foi deixar um modelo para quaisquer outra atividade extraclasse. Os roteiros (assim como o Material Complementar do texto Laboratório Multidisciplinar de Tecnologias Ambientalmente Adequadas) serviram para os estudantes que os elaboraram se organizarem para receber os visitantes, pesquisando e decidindo sobre atividades para atingir os objetivos, dividindo o tempo da visita segundo as atividades escolhidas, mas sempre de forma responsável, a começar pelo lanche servido aos estudantes. Mas a ideia em si do roteiro (ou do Material Complementar) não se restringe a essas visitas, pretende poupar o tempo do professor do ensino fundamental e médio oferecendo sugestões de atividades, onde o estudante é levado a pensar. Os estudantes devem encontrar estes alimentos observando características como forma, cor, sabor, identificando partes consumíveis e descartáveis. A partir dessa brincadeira, discute-se a riqueza nutritiva das hortaliças e o descarte dos alimentos, destacando que há partes descartadas que poderiam ser consumidas (por exemplo, folhas de beterraba e cenoura). Pergunta-se o que acontece na casa dos estudantes com a parte do alimento que é descartada. De forma lúdica, na "Gincana do lixo" cada estudante recebe um resíduo relacionado à alimentação, que pode ser orgânico ou uma embalagem de alimento, reciclável ou não reciclável.

\section{CONCLUSÕES}

Os resultados e discussão permitem concluir que os objetivos foram razoavelmente atingidos, sendo realizadas Oficinas e "Shows de Física" que permitiram a discussão, construção e instalação das tecnologias na Escola; visitas ao Centro Ecológico, que permitiram a interação com as tecnologias em funcionamento. Todas as atividades tiveram material didático especialmente produzido de apoio aos professores. 


\section{OBSERVAÇÕES FINAIS}

Deste processo e de todas estas atividades, apesar das dificuldades, ou melhor, graças a elas também, pois permitem constante evolução da parceria entre a Escola e a ESALQ quando refletidas e trabalhadas, um maior vínculo entre estes parceiros foi criado. Depois de realizado este projeto, duas novas iniciativas em parceria com o Programa Escola da Família da E.E. "Pedro de Mello" estão em desenvolvimento, também relacionadas a temas ambientais e que poderão usufruir do material e aprendizado desenvolvidos no Projeto Ciência na Escola e na Família.

\section{AGRADECIMENTOS}

Gostaríamos de agradecer aos parceiros que tornaram o Projeto Ciência na Escola e na Família possível, além de nos possibilitarem meses de muito aprendizado e enriquecedora convivência:

À direção, vice-direção e coordenação da E.E. "Pedro de Mello", que desde a elaboração do projeto nos receberam de portas abertas e nos ajudaram a realizá-lo.

Ao professor coordenador do Programa Escola da Família na Escola "Pedro de Mello", pelo seu entusiasmo, colaboração e companhia desde a idealização das oficinas até sua realização, pelo apoio nas demais atividades do Projeto e por nos possibilitar o uso do espaço desse programa, cujo espírito o Projeto Ciência na Escola e na Família compartilhou.

Ao Fomento às Iniciativas de Cultura e Extensão da Universidade de São Paulo pelo recurso financeiro disponibilizado que possibilitou a realização das oficinas e a atividade imprescindível dos dois estudantes bolsistas.

À Agência Monte Alegre de Turismo, que prontamente à apresentação do projeto, em busca de patrocínio, nos concedeu apoio com o transporte de ônibus dos estudantes para as visitas ao Centro Ecológico Flora Guimarães Guidotti.

\section{REFERÊNCIAS BIBLIOGRÁFICAS}

ARGÜELLO, G. A. Produção e desenvolvimento de equipamento para Centros de Giências. In: CRESTANA, S.; HAMBURGER, E. W.; SILVA, D. M.; MASGARENHAS, S., ed. Educação para a Ciência. Curso para Treinamento em Centros e Museus de Giência. São Paulo, Editora Livraria da Física Ltda. cap. VI, p. I45I48, 200I.

BURKE, T. J. O professor revolucionário da pré-escola à universidade. I ed. Petrópolis, Editora Vozes, 2003.

GASTRO, M. Porque tudo é sonho. In GRESTANA, S.; CASTrO, M. G.; PEREIRA, G. R. M., ed. Centros e Museus de Ciência visões e experiências - subsídios para um programa nacional de popularização da ciência. São Paulo, Saraiva, I998. p. IO5-I09.

DIMENSTEIN, G. I80 mil jovens não conseguiram ocupar 872 empregos. Folha de São Paulo, c. I4, 6 jul. 2003.

DIMENSTEIN, G.; ALVES, R. Fomos maus alunos. I. ed. Campinas, Papirus, 2003.

DRUCK, S. A crise do ensino de Matemática. Jornal da Giência, ano XVII, n. 509, p. 9-I4, II jul. 2003.

SAAD, F. D. Centros de Giências: as atuais vitrinas do mundo da difusão científica. In: GRESTANA, S.; CASTRO, M. G.; PEREIRA, G. R. M., ed. Centros e Museus de Giência visões e experiências - subsídios para um programa nacional de popularização da ciência. São Paulo, Saraiva, p. 2I-25, I998.

SAAD, F. D. Explorando o emocional do visitante durante um show de Física. In: CRESTANA, S.; HAMBURGER, E. W.; SILVA, D. M.; MASCARENHAS, S., ed. Educação para a Ciência - Curso para Treinamento em Centros e Museus de Ciência. São Paulo, Livraria da Física Ltda., 200I. cap. VII, p. I59-I6I.

SAYÃO, R. Como a escola mata a vontade de aprender. Folha de S. Paulo, f. 9, 3 jul. 2003. 


\section{APÊNDICE A}

Material Complementar do texto Laboratório Multidisciplinar de Tecnologias Ambientalmente Adequadas - Tema Compostagem

\section{SUMÁRIO}

\section{Por quê?}

2. Lixo. O que é lixo?

3. Compostagem - uma solução para não sobrecarregar o famigerado lixão

4. Como fazer o composto - passo a passo

5. Sugestões de atividades didáticas relacionadas com resíduos

5.I. Sugestão de atividade comum: montanha de lixo

5.2. Geografia

5.3. Matemática

5.4. História

5.5. Ciências

5.6. Artes

5.7. Educação Física

5.8. Língua Portuguesa

5.9. Outras sugestões de atividades para uso em disciplinas diversas

6. Bibliografia

\section{POR QUÊ??}

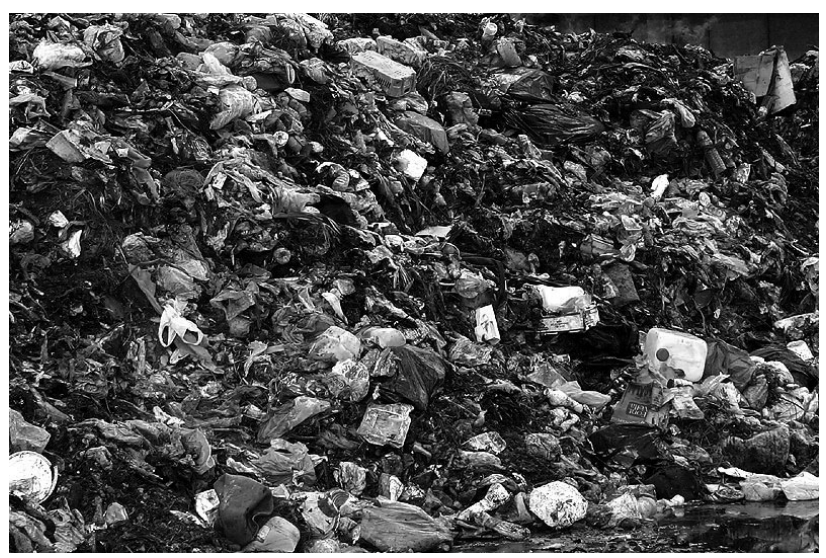

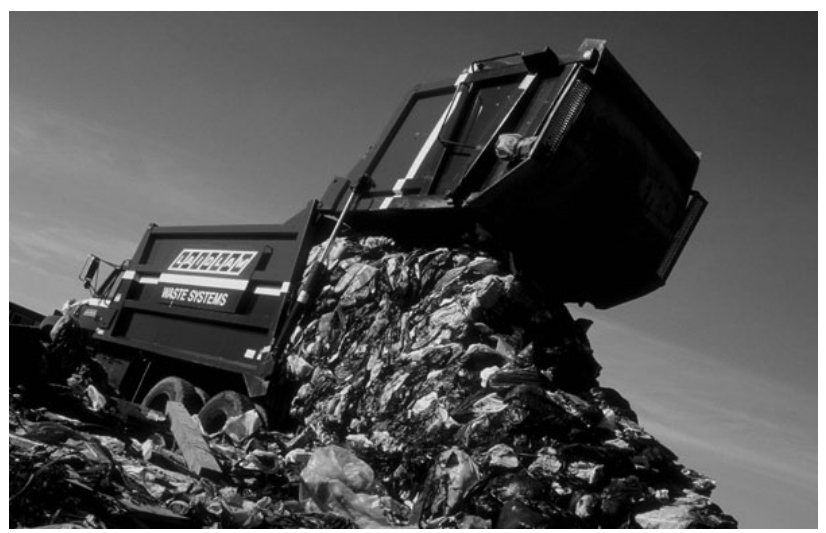

\section{LIXO. O QUE É LIXO?}

$\mathrm{Na}$ natureza todas as plantas e animais mortos apodrecem e se decompõem. São destruídos por larvas, minhocas, bactérias e fungos, e os elementos químicos que os constituem retornam à terra. Estes elementos podem ficar nos solos, rios, mares e serem utilizados novamente por plantas e então por animais. É um processo natural de reutilização. É um interminável ciclo de morte, decomposição, nova vida e crescimento.

A natureza é muito eficiente no tratamento do lixo. Na realidade, não há propriamente lixo, pois ele é novamente usado e se transforma em substâncias aproveitáveis. Enquanto a natureza se mostra eficiente em reaproveitamento e reciclagem, os seres humanos o são em produção de lixo.

O problema em deixar que apenas os ciclos naturais de decomposição e reciclagem da matéria aproveitem o lixo humano é o fato de estes serem em sua grande maioria não biodegradáveis, isto é, não se decompõem facilmente, como por exemplo, vidros, latas e alguns plásticos. Outro fator é a quantidade de lixo humano produzido por unidade de tempo. Há uma sobrecarga de lixo que vai além da capacidade da natureza em reciclar seus nutrientes.

O destino do lixo é um dos maiores problemas das cidades. Do lixo que chega a ser coletado no Brasil, mais de $75 \%$ é despejado em lixões, onde não recebe nenhum tratamento que diminua seu impacto no ambiente. Então poderá ocorrer a poluição do solo, da água subterrânea e do ar, degradando a paisagem e atraindo uma população enorme de pessoas excluídas do mercado de trabalho - estima-se que um milhão de pessoas viva da catação de resíduos nas ruas e nos lixões brasileiros! 
O lixo humano é classificado em: domiciliar, comercial, público, hospitalar, industrial, agrícola e radioativo. Pensando na preservação do ambiente, um bom destino para o lixo é a reciclagem. Reciclar é uma maneira de lidar com o lixo de forma a reduzir e reusar. Este processo consiste no reaproveitamento da matéria prima do lixo para formação de novos produtos. A mudança global é antes de tudo, uma mudança individual.

De onde vem tanto lixo? Tudo o que usamos é realmente necessário? Documentos "ambientais", como a Agenda 2I, apontam que a diminuição da quantidade de lixo depende da adoção de alguns passos básicos - os 3 R's - na seguinte ordem:

a) redução no consumo e no desperdício;

b) reutilização de produtos, e (por último)

c) reciclagem de materiais.

Reduzir o consumo - evitar a produção de lixo - certamente não é fácil na nossa sociedade urbanoindustrial, em que o avanço tecnológico, a propaganda e, fundamentalmente, a desagregação das relações familiares e comunitárias contribuem para um estilo de vida fortemente consumista. Mas esse desafio deve ser enfrentado se quisermos uma sociedade efetivamente sustentável, num planeta com recursos preciosos e finitos. Pois, como me disseram uma vez: "reciclar é pedir desculpas à natureza, enquanto reduzir é não ofender em primeiro lugar". ${ }^{2}$

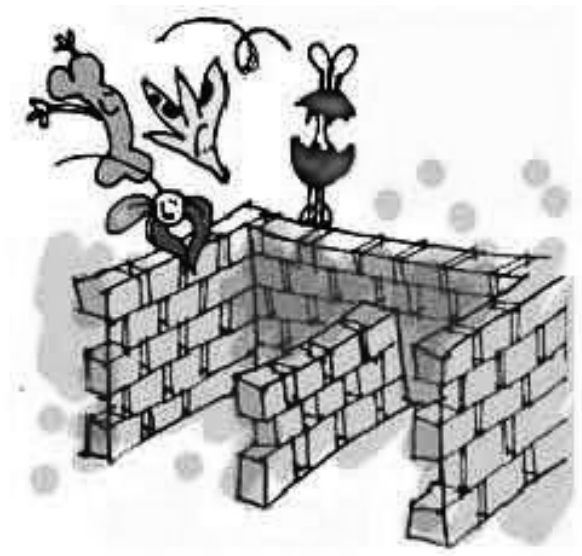

Fonte: Programa USP-Recicla

2 Excertos adaptados dos seguintes sítios virtuais: CMI Brasil-Lixo e sociedade de consumo.mht; \thiago_luciano-Aproveitamento de resíduos solidos.mht; lixo na metrópole artigo.mht; Portal SESCSP lixao.mht.

\section{COMPOSTAGEM - UMA SOLUÇÃO PARA NÃO SOBRECARREGAR O FAMIGERADO LIXÃO!}

Existem muitas boas razões para fazer um composto:

- Adicionando composto no solo, estamos devolvendo os nutrientes para a terra, zelando pela fauna do solo que também é responsável por sua fertilidade, e melhorando as condições físicas do solo;

- A matéria orgânica (erroneamente chamada de lixo) não irá preencher preciosos espaços de terra (o que ocorre em aterros sanitários, lixões, o que acarreta em poluição ambiental comprometendo aquíferos);

- Utilizar o composto nas plantas aumenta a produção de frutas e vegetais que podem alimentar sua família ou serem vendidos;

- Baratear o adubo das suas plantas.

O composto é uma cultura viva. Micro-organismos trabalham convertendo a matéria orgânica morta em uma substância farinhenta marrom que chamamos de composto. O processo de compostagem precisa de ar, água, carbono e nitrogênio. O carbono é extraído de material vegetal seco, como folhas, palha, feno, ou grama cortada seca. O nitrogênio é extraído de matéria orgânica fresca, como restos de cozinha, plantas aquáticas e esterco animal. $\mathrm{O}$ ar é adicionado com revolvimentos regulares da pilha de compostagem. A água é adicionada a partir da decomposição do material fresco e regas (caso não chova).

Pela compostagem pode-se intensificar o ciclo da vida e da morte ao mesmo tempo em que se mantém o jardim limpo. Há informações de que mais de $80 \%$ do lixo doméstico é matéria orgânica e este material pode ser processado e tornar-se solo. Reciclar a matéria orgânica de volta para o jardim faz sentido. Economiza a energia de levar os resíduos da sua casa até um depósito de lixo, e economiza um precioso espaço de terra. A matéria orgânica é qualquer coisa que um dia foi viva, portanto inclui todo o papel acumulado, restos de comida, certos tipos de cola. Muitos estudantes perceberão a importância de utilizar resíduos para criar solo fértil. 


\section{COMO FAZER O COMPOSTO - PASSO A PASSO}

a. Colete matéria seca (carbono): folhas secas, palha do arroz, feno, jornais sem cor, papelão.

b. Colete matéria fresca (nitrogênio): restos de comida, esterco de vaca, galinha ou cavalo, plantas aquática e algas.

c. Coloque uma camada de material seco de aproximadamente I-I, $5 \mathrm{~m}$ de diâmetro e I $5 \mathrm{~cm}$ de altura, em um local apropriado em seu jardim.

d. Coloque em cima uma camada de esterco de vaca, galinha ou cavalo. Adicione matéria orgânica fresca, certificando-se que o cume está ficando em forma de cúpula.

e. Repita estes passos até que todo o material tenha sido utilizado e você tenha uma pilha de I m de altura.

f. Molhe a pilha. Pare antes que a água chegue ao fundo da pilha. Utilizando uma barra de ferro ou bambu, faça um buraco de ar na pilha. Deixe a pilha descansar por quatro dias.

g. Para testar, enfie seu braço até o cotovelo na pilha. Se estiver um calor desconfortável, a temperatura será de aproximadamente $40^{\circ} \mathrm{C}$ a $50^{\circ} \mathrm{C}$. Outra alternativa é enfiar uma barra de ferro na pilha e sentir o calor no metal.

h. O que você pode dizer a respeito da temperatura? Se o calor estiver desconfortável ao toque, então a pilha está ideal.

i. Vire a pilha frequentemente para permitir a entrada de ar (mais ou menos uma vez por semana).

j. O composto estará pronto em aproximadamente $30-45$ dias para usar na horta ou para alimentar minhocas.

\section{SOLUÇÃO DE PROBLEMAS}

Algumas vezes a matéria orgânica que você colocou na pilha com tanto cuidado não se torna o tão desejado composto. Os seis próximos passos vão ajudar você a resolver alguns dos problemas mais comuns das pilhas de compostagem.

Se a pilha estiver uma massa molhada, encharcada, significa que não há ar suficiente para os organismos decompositores sobreviverem. Vire a pilha mais frequentemente para permitir que os organismos floresçam.

Depois dos primeiros quatro dias você pode pensar que não há calor suficiente na pilha. Isto geralmente significa que a pilha não está grande o suficiente. Adicione mais materiais para aumentar o volume.

Se a pilha estiver muito seca adicione mais líquidos. Podem ser misturas, como urina, água ou biofertilizante.

Quando a pilha estiver quente, mas estiver perdendo volume ou começando a cheirar amônia, significa que há muito nitrogênio. Adicione mais materiais ricos em carbono e faça uma cavidade vertical no centro da pilha utilizando uma estaca.

Se as camadas não estão quentes e estão espessas, geralmente significa que os micro-organismos ainda não começaram a trabalhar. Pique os materiais em pedaços menores e adicione alimentos ricos em nitrogênio para os micro-organismos.

Se a pilha de compostagem está cheirando e não está mudando de cor, você está criando bactérias anaeróbicas ao invés de aeróbicas. Vire a pilha mais vezes e adicione mais matéria orgânica seca.

DICAS

Nunca pise na pilha de compostagem para não compactar os espaços de ar;

Não utilize fezes de animais domésticos, como cães e gatos, pois podem transmitir doenças.

\section{COMO UTILIZAR O COMPOSTO}

Utilize o composto na horta, para melhorar a fertilidade do sistema. Pode ser utilizado na composição de adubo para plantas em vasos, ou em canteiros, é só adicionar areia de rio na proporção de I:I.

Instalar as pilhas de compostagem próximas às áreas de coleta de material orgânico e próximo ao local de uso do condicionador de solo (composto) como, por exemplo, a horta orgânica da escola.

\section{SUGESTÕES DE ATIVIDADES DIDÁTICAS RELACIONADAS COM OS RESÍDUOS}

\subsection{SUGESTÃO DE ATIVIDADE COMUM}

Esta atividade pode render aspectos para serem trabalhados em todas as disciplinas:

Montanha de lixo tem o objetivo de sensibilizar para o problema do lixo no ambiente e determinar o 
que pode ser reciclado/compostado.

Parte A: dois dias antes de iniciar o trabalho, pedir aos estudantes que anotem tudo o que jogam fora durante um dia. Peça que incluam tudo: pedaços de frutas, chicletes, garrafas, pacotes de salgadinhos, etc. Tente fazer com que incluam itens que não descartaram pessoalmente, mas que consumiram em suas casas, como caixas de leite, garrafas PET de refrigerantes, cascas de legumes do almoço, etc. A informação coletada será utilizada para um exercício futuro. Sugira a elaboração de uma tabela.

Parte B: coletar todo o lixo da turma ou da escola, durante dois dias, se o fluxo for grande, um dia só basta. Após a coleta, separar o lixo em conjunto com os estudantes em orgânico, plástico, metal, vidro, pacotes aluminizados (principalmente bolacha e salgadinho) etc. Trabalhe com os estudantes questões como: Que tipo de lixo foi coletado? Quanto pesou? Quanto desse lixo pode ser reciclado? Reutilizado? Compostado? O que fazemos com esse lixo em casa e na escola? Estimular o uso da composteira da escola pelos estudantes como um bom destino para o lixo orgânico.

\subsection{GEOGRAFIA}

SUGESTÃO DE ATIVIDADES, A PARTIR DA ATIVIDADE

MONTANHA DE LIXO (ITEM 5.1)

Conteúdos: densidade demográfica; elaboração e interpretação de gráficos; contextualização de problemas locais e globais; diferenças de hábitos em sociedades ocidentais e orientais; globalização uniformização dos hábitos; desigualdade social.

Tomando-se a média de lixo consumido por espécie/ material, calcular a média aritmética da sala e multiplicar pelo número de habitantes do distrito de Tupi, da cidade de Piracicaba, do estado de São Paulo, do Brasil, da América Latina. Os números obviamente irão aumentar. Fazer gráficos para facilitar a visualização. A proposta é alertar para a repercussão global do consumo local e individual, que na soma e no produto resultam em lixões enormes, em descuido com a natureza.

Os dados concernentes à demografia das cidades, do estado, etc. poderão ser pesquisados pelos estudantes, a partir de fontes como IBGE, enciclopédias atualizadas, Google Earth, internet, etc.
Após a coleta de dados e interpretação, propor uma exposição de cartazes com tabelas, imagens, desenhos, colagens, que ilustrem e demonstre quanto lixo é consumido, qual o resíduo de maior magnitude. Provocar reflexões do tipo "e se toda a população mundial tivesse os mesmos hábitos de vida que nós ocidentais, como seria o mundo?”. Apontar para o problema, mas salientar as possíveis soluções, como a redução do consumo.

Posturas como a preferência por alimentos mais naturais, menos embalados, consumo direto do produtor, opção por produtos orgânicos, são soluções práticas e possíveis para a questão alarmante do lixo e do consumo inconsequente.

O professor pode optar por fazer um debate ou redação com os estudantes após a tabulação e interpretação dos dados. Podem ser feitos paralelos com a miséria de alguns que vivem do lixo dos outros (ver textos de apoio). Que o problema do lixo é um problema complexo de logística, pois se fosse estocado, catalogado, seria com certeza buscado por quem o procura e precisa. Mas será que precisamos de tudo o que temos para sobreviver? Proponha que os estudantes elaborem listas do que realmente precisam para sobreviver, o que no quarto deles poderia ser descartado. Precisam realmente de tantos brinquedos? Do videogame de última geração?

Problemáticas do tipo: o consumo da zona rural é o mesmo da zona urbana? Por quê? Como seria o lixo desse pessoal? Pedir aos estudantes que listem o que haveria no lixo dessas pessoas. Facilitaria se tivesse alguém da sala de aula que tem algum parente que mora numa chácara ou o próprio estudante. Esse exercício é interessante, pois geralmente na zona rural os resíduos sólidos são orgânicos. Por que nas zonas urbanas consumimos mais lixo?

Pensar nos apelos da publicidade para vender qualquer coisa. Pode ser feita uma atividade em paralelo com as artes, em que o professor escreve em tiras de papel nome de objetos, resíduos, como por exemplo, pneu de bicicleta usado, clipes de papel, borracha usada, potes de iogurte, etc. Sortear um papel para cada três alunos, pedir que eles desenvolvam um produto com isso, e que vendam esse produto, fazendo uma propaganda apelativa. Assim os estudantes compreenderão que o valor dos objetos é cultural, pois algo sem valor essencial à sobrevivência, como uma roupa da moda, pode ter valor agregado se for feita uma propaganda apelativa que o torne 
atraente, que seja impositivo para que você tenha algum valor ao adquiri-lo. É o verdadeiro "ter é ser" (ver textos de apoio). Pedir que apresentem o produto ao final do semestre.

\section{TEXTO DE APOIO}

\section{Eu, Etiqueta}

\section{Carlos Drummond de Andrade}

Em minha calça está grudado um nome que não é meu de batismo ou de cartório, um nome...estranho.

Meu blusão traz lembrete de bebida que jamais pus na boca, nesta vida. Em minha camiseta, a marca de cigarro que não fumo, até hoje não fumei. Minhas meias falam de produto que nunca experimentei mas são comunicados aos meus pés Meu tênis é proclama colorido de alguma coisa não provada por este provador de longa idade.

Meu lenço, meu relógio, meu chaveiro, minha gravata e cinto e escova e pente, meu copo, minha xícara, minha toalha de banho e sabonete, meu isso, meu aquilo desde a cabeça, ao bico dos sapatos, são mensagens, letras falantes, gritos visuais, ordens de uso, abuso, reincidência, costume, hábito, premência, indispensabilidade, e fazem de mim homem-anúncio itinerante, escravo da matéria anunciada.

Estou, estou na moda.

É doce estar na moda, ainda que a moda seja negar a minha identidade, trocá-la por mil, açambarcando todas as marcas registradas, todos os logotipos do mercado. Com que inocência demito-me de ser eu que antes era e me sabia tão diverso de outros, tão mim-mesmo, Ser pensante, sentinte e solidário com outros seres diversos e conscientes de sua humana, invencível condição.

Agora sou anúncio, ora vulgar ora bizarro, em língua nacional ou em qualquer língua (qualquer, principalmente).

E nisto me comprazo, tiro glória de minha anulação.

Não vou - vê-la - anúncio contratado.

Eu é que mimosamente pago para anunciar, para vender em bares festas praias pérgulas piscinas, e bem à vista exibo esta etiqueta global no corpo que desiste de ser veste e sandália de uma essência tão viva, independente, que moda ou suborno algum a compromete. Onde terei jogado fora meu gosto e capacidade de escolher, minhas idiossincrasias tão pessoais, tão minhas que no rosto se espelhavam, e cada gesto, cada olhar, cada vinco da roupa resumia uma estética? Hoje sou costurado, sou tecido, sou gravado de forma universal, saio da estamparia, não de casa, da vitrina me tiram, recolocam, objeto pulsante mas objeto que se oferece como signo de outros objetos estáticos, tarifados.

Por me ostentar assim, tão orgulhoso de ser não eu, mas artigo industrial, peço que meu nome retifiquem. Já não me convém o título de homem. Meu nome novo é coisa.

Eu sou coisa, coisamente.

\subsection{MATEMÁTICA}

\section{SUGESTÃO DE ATIVIDADES, A PARTIR DA ATIVIDADE} MONTANHA DE LIXO (ITEM 5.1)

Conteúdo: números racionais; frações; decimais; porcentagem; interpretação de situações: problemas e gráficos de funções lineares simples; coleta e tabulação de dados; média aritmética; operações aritméticas.

Elaboração de gráficos a partir dos resultados da análise dos tipos de lixo encontrados. 
Pese ou conte (quantidades) e estabeleça relações, por exemplo, foram amostrados no lixo da escola IO garrafas de refrigerante PET num total de 20 embalagens de material plástico, o que significa IO/20 $=50 \%$ do material plástico encontrado é do tipo garrafas PET.

Para a aula seguinte, peça que os estudantes tragam as listas elaboradas na Parte A, assim, o professor pode fazer análises comparativas entre o consumo individual com o todo, por exemplo, pode na lousa, dividida por qualidade do material (vidro, plástico, orgânico, metal, etc) ir somando toda a sala e pedir para que cada estudante relacione o seu material ao todo da sala de aula. Por exemplo, Mariana tem na sua lista (um dia anotando os resíduos) 6 potes de iogurte, material plástico, supondo-se que na sala de aula o total de resíduos do tipo plástico seja 60, Mariana em relação à sala de aula, consumiu IO\% dos resíduos sólidos de plástico, o que é consideravelmente alto, dependendo do número de estudantes. É importante salientar o papel do professor na interpretação dessas relações, para que o estudantes compreendam a importância do reuso, da reciclagem, e da redução do consumo de alimentos industrializados, que geralmente estão envolvidos por diversas e numerosas embalagens. Uma tabela de coleta de dados pode ser feita pelos estudantes, como no exemplo abaixo:

\section{Tabela: Coleta de Dados}

Tipo de material:

Estudante:

Escola/ Sala:

Relação Estudante/ Escola ou sala:

Vidro:

Plástico:

Papel:

Orgânico (restos de alimentos, etc):

Metais:

Outros:

MAIS SUGESTÕES RELACIONADAS COM A

\section{ATIVIDADE 1:}

O professor pode propor problemas para atividade anterior como do modelo abaixo:

I. Sabendo que a produção diária de lixo no Brasil é estimada em 228.500 toneladas, qual a quantidade média do lixo produzida por cada habitante em um dia?

Resposta: considerando uma população de I80 milhões de habitantes, o resultado é de I, $26 \mathrm{~kg} /$ dia.

II. Após a atividade, responder, qual resíduo sólido reciclável é gerado em maior quantidade (volume) nesta escola? (plásticos, madeiras, podas, sobras de alimentos, papéis, metais, vidros, outros).

III. Calcular quantos copos descartáveis são utilizados por I500 estudantes, que utilizam um restaurante duas vezes ao dia, durante quatro anos letivos (de aproximadamente 9 meses cada)?

Resposta: considerando que este restaurante escolar não funciona aos finais de semana, um mês com 20 dias letivos x 4 anos x 3000 copos/dia, o resultado é: 2.160 .000 copos descartáveis.

\subsection{HISTÓRIA}

\section{SUGESTÃO DE ATIVIDADES, A PARTIR DA ATIVIDADE}

MONTANHA DE LIXO (ITEM 5.1)

Conteúdos: comunidades coletoras/ sedentárias; história das guerras e conquistas de territórios - conservação dos alimentos; linha do tempo.

Os estudantes podem ser instigados a descobrir a história de um determinado resíduo, desde sua fabricação até destino final, num lixão, e o final poderá ser feliz, se for outro, na reciclagem, na compostagem, etc. Como exemplo, um pacote de salgadinhos, muito popular no meio escolar, o salgadinho é de milho, que é plantado na terra, o óleo de soja é utilizado para fritar ou assar, o sal vem do mar. O pacote é plástico, com metal alumínio. O plástico é um polímero que é fabricado a partir do petróleo, e o alumínio é extraído da terra, é um mineral. Assim o estudante pode fazer uma narração sobre materiais. Esse exercício propiciará um contato mais direto com o resíduo, como um abrir de olhos, um alerta para as condutas de consumo.

A atividade 2 de Ciências pode ser adaptada para a disciplina de História.

O tempo pode ser abordado nas práticas I e 2 propostas pela aula de ciências naturais, assim pode-se solicitar aos estudantes que tracem linhas do tempo, lineares e circulares, do desenvolvimento da planta no caso da atividade I em ambos os casos, e do desenvolvimento e decomposição dos objetos enterrados na atividade 2. Cada 
objeto pode ficar sobre a responsabilidade de um trio de estudantes para que possam juntos fazer esta linha do tempo, que no caso pode ser circular, pois alguns dos resíduos retornam ao solo. Noções de tempo circular, do retorno, da ciclagem podem ser abordadas. Um histórico deverá ser elaborado. Sendo anotado o comportamento de cada material enterrado a cada semana, ou em cada aula de história, pois assim, tem-se um contato prático com o tempo.

\subsection{CIÊNCIAS}

\section{SUGESTÃO DE ATIVIDADE 1}

Objetivo - Observar a importância do composto na fertilidade do solo.

Material - Terra do jardim e composto, 2 vasos, 2 mudas de couve ou outra hortaliça prontas para transplantar, fita crepe e marcador, papel (anotações).

Método - Marque os vasos I e 2, encha um vaso com terra do jardim e rotule como vaso I, encha o segundo vaso com a terra e o composto na proporção de I:I e rotule como vaso 2. Coloque uma planta em cada vaso. Cuide das duas plantas exatamente do mesmo modo nas próximas semanas. Coloque água ao mesmo tempo e dê a elas a mesma quantidade de sol. Anote os resultados em seu diário. Peça aos estudantes para observar durante quatro semanas: Qual planta parece estar mais saudável? Qual está maior? As folhas nas duas plantas são da mesma cor? Qual planta produziu flores? Qual planta teve mais problemas com insetos? Qual é a altura das plantas? Fazer um gráfico do crescimento das plantas ao longo dos dias (fazer medições a cada dois dias, com uma régua).

Observação: Seria interessante propor essa atividade para duplas, ou trios, pois assim a responsabilidade de coletar dados fica dividida, e há um momento propício para indagações em grupo, discussões, o que enriquece muito a formação dos estudantes.

\section{SUGESTÃO DE ATIVIDADE 2}

Objetivo - Observar a decomposição dos materiais.

Material - um pedaço de plástico, papel, alumínio (latinha), solo, noz (inteira), miolo de maçã (casca de banana, etc.), um pedaço de vidro, grãos de feijão, um local no chão do jardim, que não seja mexido em 30 dias.
Método - Cavar um buraco de aproximadamente $12 \mathrm{~cm}$ de profundidade. Enterre cada objeto em um buraco separado - alguns grãos de feijão, miolo de maçã, pedaços de vidro, nozes, papel, alumínio, e um pedaço de plástico. Cubra os buracos com terra. Pelo próximo mês regue os buracos 2 a 3 vezes todos os dias. Depois de 30 dias, desenterre tudo e observe as diferenças. Para facilitar a localização, fincar um pedaço de galho de árvore, ou outro objeto que seja de fácil visualização. Anote as observações em seu diário. Quais objetos se decompõem mais rápido?

Dica: utilizar como material a ser enterrado, coisas retiradas da lixeira do pátio da escola (a lista acima é apenas uma sugestão, podem ser outros materiais, os disponíveis sempre são os melhores!), pois assim ocorre uma extensão do conhecimento, ou seja, o estudante irá associar o que é resíduo orgânico e inorgânico dentro do universo de seu consumo, que está registrado nos resíduos contidos na lixeira da escola.

Observação: as aulas práticas seriam no jardim da escola, ao lado da composteira já instalada.

\subsection{ARTES}

\section{A) ARTES VISUAIS}

Conteúdo: Artes Visuais: textura, cor, imagem, formas do material.

Sugestões de atividade: após uma breve explanação do que é uma composteira, o que é composto (dando ênfase ao caráter orgânico dos materiais), o professor solicitará aos alunos que se organizem em grupos, para a coleta de terra, de todos os tipos, areias, argilas, composto da composteira (matéria orgânica decomposta). Solicite que os estudantes dirijam-se a diferentes locais, com paisagens diferenciadas, por exemplo, nas margens de rios as argilas são escuras, acinzentadas, já numa plantação de cana de açúcar o solo geralmente é bem vermelho, etc. Cada grupo deverá levar para a sala de aula o material coletado. O professor poderá propor uma paleta de cores com as argilas coletadas, misturando as terras, propondo o uso desse tipo de material aos estudantes, explicitando o caráter natural, orgânico, diferente de uma tinta acrílica, por exemplo. 


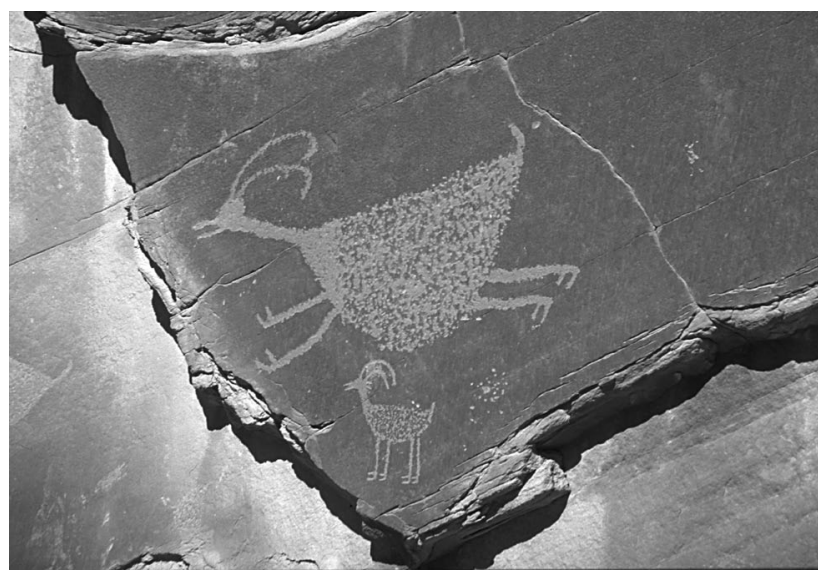

Poderão fazer colagens com a terra, misturando uma parte de água, meia parte de cola do tipo PVA para duas partes de argila, assim a terra irá grudar na tela ou papel, não se desprendendo após a secagem. No caso das areias, seria interessante a aplicação de cola no local desejado, para prender a areia, fazendo uma colagem como usualmente se faz com purpurina.

Dica: para facilitar a compreensão de que um material orgânico foi algo vivo, o professor pode solicitar a coleta de flores (pode ser feita a secagem destas a partir da prensagem), folhas, frutos, cascas de frutas (de frutas cítricas - geralmente parecem um couro quando secas; são boas para desenhos geométricos, metades de casca de laranjas podem servir de portatrecos, etc.), casca de ovos (ótimo para confecção de mosaicos), para trabalhar a forma, a cor, a textura. Pode ser proposta outra atividade para dar continuidade ao entendimento dessa técnica "naturalista".

No contexto histórico das Artes, o professor pode falar sobre as comunicações anciãs dos humanos com as pinturas rupestres em cavernas (figura acima). Quais materiais eram utilizados nessa comunicação? Por que utilizavam esses materiais?

Observação: o professor poderá trabalhar com essa técnica a partir do primeiro ciclo do Ensino Fundamental. Na realidade, pode ser trabalhado em todos os ciclos, divergindo apenas na metodologia, mas o conteúdo, utilização de material orgânico nas artes visuais, é mantido.

\section{B) DANÇA}

Sugestões de atividade: o educador pode escolher danças como tema semestral, por exemplo, as africanas, garantindo a transversalidade do tema
Pluralidade Cultural, presente nos PGN's do Ensino Fundamental brasileiro. A cultura afro-brasileira pode ser, por exemplo, um tema semestral, para compreender como influenciou e influencia a cultura popular brasileira, e até a erudita.

A dança dos povos mais "primitivos" é rica e desempenha papel social importante nessas sociedades. Compreender a relação desses povos com a natureza, suas construções arquitetônicas (por exemplo, casas com tijolos de terra crua na África). A relação desses povos com a terra é de enorme valia para que os estudantes tentem compreender que não existe somente uma visão técnica-científica de mundo, como geralmente ocorre nos grandes grandes centros urbanos.

O "resgate" desses valores com a terra pode ser conectado a partir dessa comunhão cultural brasileira com a África. Sambas enredos que entoam a colheita, o trabalho, a labuta, o lavrar da terra, o cuidado com o ambiente, com os outros seres. Valores estes que devem permear toda a jornada escolar desses estudantes, para que fiquem mais atentos aos apelos da mídia no que concerne ao consumo exacerbado de bens materiais, e consequentemente poluição da paisagem, da terra, das relações humanas, como é o caso do lixo.

Outras sugestões: abordar as danças tribais, indígenas, aborígine, afro-brasileira, danças folclóricas. Utilizar desenhos tribais, palhas, penas, folhas, tinta de terra, urucum, cenário, vestuários de materiais orgânicos.

O interessante desses tipos de dança é que os meninos, geralmente avessos às danças, podem se interessar, uma vez que em danças tribais e tradicionais, os homens dançam para guerrear, lutar, casar, exercendo a função social e cultural do "masculino", e as mulheres do "feminino" (embora em algumas culturas esses papéis socioculturais estejam invertidos). Isso poderá facilitar a participação dos meninos nas danças.

Para facilitar a realização da coreografia, da pesquisa, o diálogo pode ser feito com os responsáveis pelas disciplinas de Educação Física, Língua Portuguesa, História e Geografia.

A apresentação da dança poderá ser feita com todas as turmas de todos os ciclos, integrando as diversas idades, facilitando um relacionamento entre as diferentes faixas etárias, proporcionando um diálogo e intercâmbio de valores comportamentais entre eles.

O professor pode optar por uma aula de dança circular, tipo ciranda, onde no centro pode ser 
concentrado todo o material orgânico coletado pelos estudantes, sendo uma oferta para a ciranda, flores, arbustos, etc. A música da ciranda pode abordar a temática da matéria orgânica, da matéria viva.

\section{C) MÚSICA}

Sugestões de atividades: confecção de instrumentos musicais utilizando material orgânico. Similar à aula de coleta de solos, o professor poderá solicitar a coleta de frutos, sementes, pedaços de tronco, coités, cabaças, colmos de bambu, flores, etc.

Podem ser feitos chocalhos com as coités, cabaças e sementes, berimbaus, pequenos tambores (com o bambu, ao invés do couro pode ser utilizado um plástico lona resistente), galhos podem tornar-se baquetas que batem no bambu (tambor de língua), reco-reco de bambu, etc. Cada estudante pode ser responsável pela pesquisa de seu instrumento (em livros, na rede de computadores, etc), assim, poderá escolher o instrumento, o material que mais o atraia. A turma de estudantes pode ser ensinada utilizando um tambor ou mesmo batendo a baqueta numa mesa, para dar a sensação das quartas, oitavas, etc. $\mathrm{O}$ bater palmas também é interessante, e também pode ser trabalhado como instrumento musical.

Observação: Essa aula pode ser realizada em qualquer faixa etária ou ciclo do Ensino Fundamental, o critério de adesão dos estudantes virá do contato do professor com a turma.

\section{D) TEATRO}

Sugestões de atividades: uma peça, ou uma performance sobre reciclagem da matéria orgânica pode ser realizada. O roteiro geral seria a destinação dos alimentos vivos no lixão, um lugar "morto", feio e inóspito. Assim, os atores seriam os alimentos orgânicos descartados por uma dona de casa, e como eles temem o destino para o lixão, e como sonham em morar com as lindas flores e árvores, num solo onde seriam amigos das minhocas e garantiriam sua metamorfose em composto orgânico, um nobre e desejado fim, ou melhor, um não-fim, um infinito refazer-se, uma reciclagem, um ciclo (seria interessante entrar com a dança, as cirandas, pois por serem cíclicas dão noção de reciclagem). Um narrador pode contar o roteiro desses alimentos orgânicos, seus sentimentos e dilemas, utilizando dados estatísticos sobre a realidade nacional (com dados estatísticos, por exemplo, o número de municípios com coleta seletiva no estado de São Paulo) no que diz respeito ao mau/bom gerenciamento do destino/reaproveitamento de resíduos orgânicos. Utilizar figurino e cenários feitos de material reciclado pelos próprios estudantes ao longo do semestre. Como exemplo, o uso de máscaras de papel maché (técnica de reutilização do papel, utilizando cola de goma).

Observação: Não há restrições quanto a idade ou ciclo e série. A interpretação e atuação pode envolver todos ou não, há atividades como confecção das roupas, cenário, da pesquisa sobre o gerenciamento dos resíduos que podem envolver os que não desejam atuar.

Dica: trabalhar como tema semestral o uso dos resíduos orgânicos nas artes. Procurar o auxílio, no caso do teatro, de professores da área de ciências naturais, especialmente para explicar a "metamorfose" desses materiais orgânicos. A Educação Física pode auxiliar também, na coreografia, na postura, nos movimentos do corpo, etc. A Língua Portuguesa se incumbirá da redação do roteiro e da interpretação do texto, por exemplo. É importante o diálogo entre as disciplinas e entre os professores.

\subsection{EDUCAÇÃO FÍSICA}

\section{SUGESTÕES DE ATIVIDADE: JOGO "RATOSE URUBUS".}

É um jogo de pega-pega em que dois times - o dos Ratos e dos Urubus - interagem em função das frases cantadas pelo educador. Quando a frase é verdadeira, os Urubus correm para pegar os Ratos e os $\mathrm{Ra}$ tos fogem em direção do pique. E se for falsa, os Ratos correm para pegar os Urubus e estes fogem! Elabore uma lista de aproximadamente 20 afirmativas, sendo IO verdadeiras e IO falsas, sobre o tema específico que se deseja apresentar ou avaliar.

Desenhe uma linha com giz para separar o campo dos Ratos e dos Urubus, faça um pique no fundo da quadra de cada um.

Explique às equipes que você falará em voz alta e pausadamente algumas afirmativas falsas e outras verdadeiras. Quando a frase for verdadeira, o grupo dos Urubus deve pegar o grupo dos Ratos. Ao contrário, se a afirmativa for falsa, o grupo dos Ratos deve pegar os membros do grupo dos Urubus. 
Quando um membro for capturado, ele será incorporado ao grupo que o capturou. Quando aquele que estiver fugindo ultrapassar a marca da fuga estará a salvo, ou seja, não poderá mais ser pego por ninguém do outro grupo. Assim uma pessoa pode ser pega somente na região delimitada entre a linha do meio e a linha de fuga.

Assim que o moderador "cantar" uma afirmativa, cada pessoa (sozinha) faz o julgamento rápido se ela é falsa ou verdadeira, então corre para "pegar" ou para "fugir", dependendo da equipe da qual faz parte. Depois de todos pararem de correr, ou seja, foram pegos, ou estão na área de fuga, o educador pode revelar a resposta certa (se a afirmativa é falsa ou verdadeira) e então cada participante fica sabendo se correu para o lado certo e se deve mudar de time ou não.

Às vezes, a resposta gera polêmicas ou alguns participantes perguntam sobre os porquês. Nesses casos, faça comentários breves, tentando não quebrar o ritmo do jogo e lembrando ao grupo que todas as questões serão debatidas e esclarecidas ao final.

Depois de encerrada a partida, entregue a cada participante uma folha com todas as afirmativas, mas sem as respostas (verdadeiro ou falso). Conduza uma roda de conversa para esclarecimentos e debates sobre cada uma das frases.

\section{EXEMPLOS DE QUESTÕES:}

\section{Afirmativas relacionadas ao tema lixo}

I. Gada brasileiro produz, em média, 300 gramas de lixo por dia. (F)

II. Na Europa, a responsabilidade de reduzir o impacto ambiental das embalagens ao mínimo é do fabricante. (V)

III. Mais de 60\% dos municípios brasileiros destinam seus resíduos sólidos para lixões e aterros sanitários. (V)

IV. Destinar adequadamente os pneus já usados não é obrigação dos fabricantes de pneus. (F)

V. No Brasil, o percentual de vidro reciclado é IO०\%. (F)

VI. A legislação brasileira exige que todos os resíduos provenientes de hospitais sejam incinerados. (F)

VII. A legislação da União Européia prevê o desenvolvimento da utilização de materiais reciclados na fabricação de veículos. (V)
VIII. No Brasil, os catadores autônomos coletam mais recicláveis do que os programas municipais de coleta seletiva. (V)

IX. A disposição inadequada do lixo pode contaminar águas subterrâneas. (V)

X. No Brasil, a coleta seletiva está mais presente nos estados do Sul e Sudeste. (V)

XI. A Agenda 2I possui um capítulo sobre mudança nos padrões de consumo. (V)

XII. A porcentagem de embalagens PET recicladas no Brasil é de 90\%. (F)

XIII. No Brasil, a reciclagem de latas de alumínio supera a de países desenvolvidos. (V)

XIV. A legislação brasileira permite que algumas pilhas sejam dispostas em aterros sanitários. (V)

XV. O plástico mais reciclado no Brasil é o PET. (V)

XVI. A produção de 250 g de carne bovina requer aproximadamente 25.000 litros de água. (V)

XVII. Cerca de metade do chumbo consumido hoje vem de fontes recicladoras. (V)

XVIII. O Brasil recicla mais de $70 \%$ das latas de alumínio. (V)

XIX. A coleta seletiva no Brasil atende mais de $30 \%$ das residências. ( $F$ )

XX. Para fazer uma calça jeans, utiliza-se de IO a 20 metros quadrados de algodão. (V)

XXI. Atualmente, $25 \%$ da população do mundo consome $75 \%$ dos recursos naturais do planeta. (V)

XXII. A maior parte do lixo no Brasil é reciclada. (F)

XXIII. A reciclagem é a solução para a questão do lixo. (F)

XXIV. No Brasil, cerca de 5.000 municípios realizam programas de coleta seletiva. (F)

XXVI. Cerca de 30\% do volume do lixo sólido descartado numa cidade brasileira corresponde a embalagens plásticas. (V)

XXVII. Os países industrializados geram cerca de $90 \%$ dos rejeitos perigosos do mundo inteiro. (V)

Fonte: SUDAN et al. 


\subsection{LÍNGUA PORTUGUESA}

\section{SUGESTÃO DE ATIVIDADE 1}

Observar a imagem e ler textos para auxílio. Elaborar um texto de gênero literário à escolha do professor sobre uma imagem, como a que está abaixo:

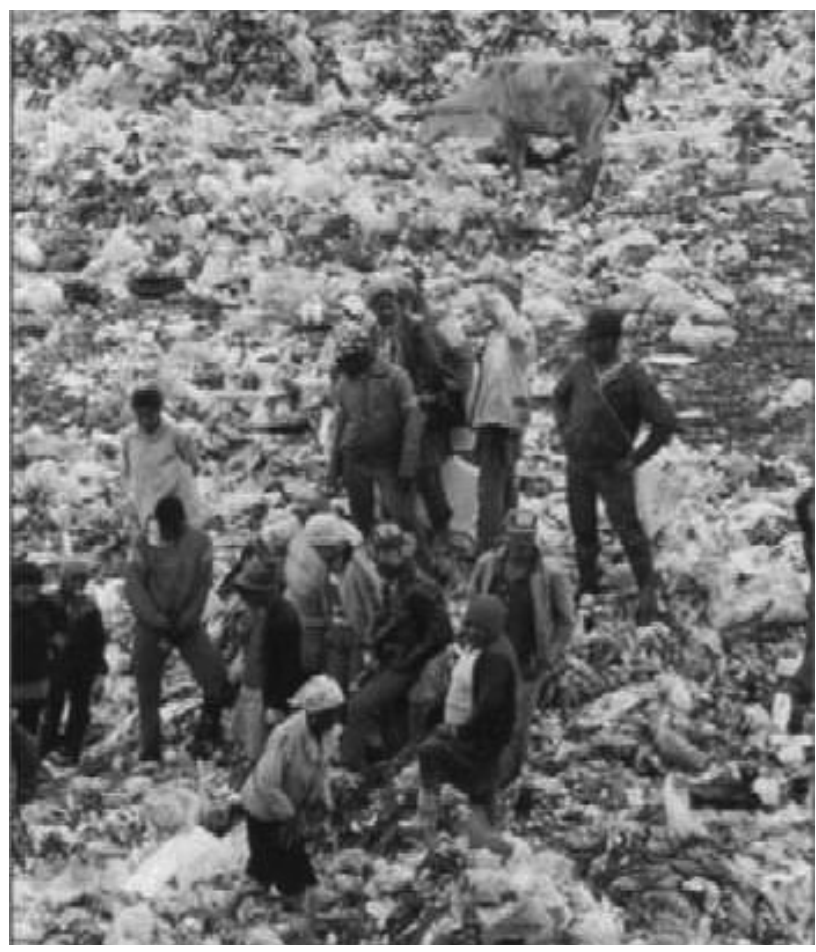

\section{TRECHOS REFLEXIVOS PARA AUXILIAR}

"A principal característica do lixo orgânico é a possibilidade da decomposição com intervalos relativamente curtos. Mandar o lixo orgânico para os aterros sanitários, através da coleta pública é um enorme erro, uma saída muito fácil, mas uma atitude criminosa contra o ambiente. A Natureza não é uma lixeira, e temos que mudar nosso comportamento com relação ao lixo orgânico, pois os prejuízos são enormes: coleta extremamente cara, proliferação de doenças entre as pessoas que buscam alternativas de sobrevivência nos aterros sanitários, situação ideal para o desenvolvimento de insetos transmissores de doenças, produção do chorume altamente poluente dos solos e dos lençóis freáticos.” 3

3 Disponível em: 〈www.cenedcursos.com.br/lixo-organico-zero.html〉. Acesso em: 24 jan.2008.

\section{O Bicho}

\section{Manuel Bandeira}

Vi ontem um bicho

$\mathrm{Na}$ imundice do pátio

Catando comida entre os detritos,

Quando achava alguma coisa,

Não examinava nem cheirava;

Engolia com voracidade.

O bicho não era um cão,

Não era um gato,

Não era um rato.

O bicho, meu Deus, era um homem.

\section{Bichos Escrotos \\ Titãs}

Bichos, saiam dos lixos.

Baratas, me deixem ver suas patas.

Ratos, entrem nos sapatos

Do cidadão civilizado.

\section{SUGESTÃO DE ATIVIDADE 2}

Solicitar aos estudantes que façam pesquisas em jornais, revistas ou outros meios de comunicação escrita, sobre matérias envolvendo lixo, seus problemas e soluções. Sugerir que formem grupos e que elaborem um cartaz para ser exposto no pátio da escola, com essas reportagens e com pesquisa de dados por parte dos estudantes. Esse tipo de atividade irá estimular o pensamento crítico do estudante em relação ao que é exposto nos meios de comunicação sobre o lixo. Solicitar que procurem exaltar as soluções para as questões do lixo, que estarão expostas nas reportagens.

\subsection{OUTRAS SUGESTÕES DE ATIVIDADES PARA USO EM DISCIPLINAS DIVERSAS}

a) Com o tema dos resíduos sólidos, solicite aos estudantes recortes de jornais e revistas com imagens dos problemas do lixo, do descuido, do consumismo. Depois, solicite que essa mesma turma traga recortes sobre como deveria ter sido cuidado o lixo. Colar em duas cartolinas, uma com o problema, a outra com a solução. Reunir a sala em círculo 
e discutir sobre o resultado.

b) Solicitar que cada estudante escreva em formato narrativo o que consumiu em um dia. Reuni-los em grupos de cinco para que discutam o que consumiram. Cada grupo deverá fazer uma lista dos itens consumidos por todos os seus membros e depois expor os resultados à sala.

c) Solicitar aos estudantes que sentem-se formando um círculo. Colocar um saco com muita e variada sucata no centro do círculo (sala de aula ou pátio) e iniciar uma narração como as seguintes sugestões: "Quando eu estava na beira do rio pescando, pensei ter pescado um peixe, mas na verdade pesquei..."; "Todo mundo precisa, é vital, é muito importante ter isso..."; "Quando eu tiver netos quero que eles ganhem de presente um/a...”; etc. Daí, você retira um objeto, e completa a história. O professor pode iniciar com uma dessas frases norteadoras, assim os estudantes irão um a um (sentido horário) completar a história. Por exemplo, na primeira frase, você tira do saco de sucatas uma meia velha, “...mas pesquei uma meia velha, ainda pescando encontrei na margem do rio..."; daí o próximo estudante vem e forma a próxima linha, e assim há uma história sendo tecida em torno da questão dos resíduos.

\section{REFERÊNCIA BIBLIOGRÁFICA}

SUDAN et al. De pá virada: Revirando o tema lixo. Vivências em educação ambiental e resíduos sólidos. São Paulo, Programa USP Recicla/ Agência USP de Inovação, 2007. 245 p.

LEGAN, L. A escola sustentável: eco-alfabetizando pelo ambiente. 2. ed., atualizada e revisada. São Paulo, Imprensa Oficial do Estado de São Paulo; Pirenópolis, Ecocentro IPEC, 2007. $184 \mathrm{p}$.

〈www.lixo.com.br〉. Acesso em: 28 jan. 2007.

<http://www.pontoterra.org.br〉. Acesso em: 28 jan. 2007.

$<$ http://www.reciclarepreciso.hpg.com.br $>$. Acesso em: 28 jan. 2007.

<www.cenedcursos.com.br/lixo-organico-zero.html>. Acesso em: 24 jan. 2008. 


\section{APÊNDICE B}

\section{ROTEIRO DA VISITA DE TEMA COMPOSTAGEM}

\section{OBJETIVOS}

Expansão do conhecimento dos estudantes sobre a ciclagem de resíduos orgânicos e sobre a problemática da geração de lixo. Estimular a prática dos 3 R's.

\section{APRESENTAÇÃo}

Em círculo, cada participante se apresenta, anota o nome num papel e cola no peito, facilitando a identificação.

\section{DESENVOLVIMENTO}

A turma é dividida em dois grupos, um para cada monitor, e realizarão as mesmas atividades em momentos diferentes: sistema agroflorestal ou horta orgânica. Em seguida, se encontrarão na atividade "Gincana do lixo".

No sistema agroflorestal e na horta orgânica são distribuídos aos estudantes fichas com o nome de alimentos/espécies florestais cultivadas nas áreas. Os estudantes devem encontrar estes alimentos observando características como forma, cor, sabor, identificando partes consumíveis e descartáveis. A partir dessa brincadeira, discute-se a riqueza nutritiva das hortaliças e o descarte dos alimentos, destacando que há partes descartadas que poderiam ser consumidas (por exemplo, folhas de beterraba e cenoura). Pergunta-se o que acontece na casa dos estudantes com a parte do alimento que é descartada.

$\mathrm{Na}$ "Gincana do lixo" cada estudante recebe um resíduo relacionado à alimentação, que pode ser orgânico ou uma embalagem de alimento, reciclável ou não reciclável. Como exemplo de resíduo orgânico temos casca de banana, casca de mexerica, folha de cenoura, filtro de café de papel usado. Exemplo de embalagens recicláveis: lata de refrigerante, garrafa $\mathrm{PET}$, pote de margarina, lata de conserva, vidro de geleia, caixinha de leite, saquinho de leite. Exemplos de embalagens não recicláveis: pacotes aluminizados de bolacha, pacote aluminizado de salgadinho, embalagens de isopor.

Gada estudante falará sobre seu resíduo, tentando discernir se é orgânico, reciclável ou não reciclável.
Então colocará seus resíduos no cesto apropriado, no centro da roda, e dirá do que é feito esse alimento. Para os restos orgânicos será fácil, para as embalagens será necessário ler os ingredientes do produto. Em seguida, serão discutidos os destinos de cada tipo de resíduo e o princípio dos 3 R's. Também podem ser discutidos os ingredientes dos alimentos industrializados que comemos, estimulando uma alimentação saudável.

Por fim, os resíduos orgânicos são levados para a composteira onde se conversa sobre o processo de decomposição da matéria orgânica. Mostra-se a fauna existente na composteira, responsável pela decomposição. Mostra-se a utilização do composto na horta e a ciclagem que esse reaproveitamento dos resíduos proporciona. 